\title{
Oestrogens regulate pituitary $\alpha 2,3$-sialyltransferase messenger ribonucleic acid levels in the female rat
}

\section{P Damián-Matsumura ${ }^{1,2}, \mathrm{~V}_{\text {Zaga }}{ }^{1,2}$, A Maldonado ${ }^{2}$, C Sánchez-Hernández ${ }^{2}, C_{\text {Timossi }}{ }^{1,3}$ and A Ulloa-Aguirre ${ }^{1}$}

${ }^{1}$ Department of Reproductive Biology, Instituto Nacional de la Nutrición Salvador Zubirán, Mexico

${ }^{2}$ Department of Reproductive Biology, Universidad Autónoma Metropolitana-Iztapalapa, Mexico

${ }^{3}$ Department of Pharmacology, Faculty of Medicine, Universidad Nacional Autónoma de México, México DF, Mexico

(Requests for offprints should be addressed to A Ulloa-Aguirre, Department of Reproductive Biology, Instituto Nacional de la Nutrición SZ, Vasco de Quiroga No. 15, Tlalpan 14000, México DF, Mexico)

(P Damián-Matsumura, A Maldonado, C Timossi and A Ulloa-Aguirre are now at Research Unit in Reproductive Medicine, Hospital de Gineco-obstetricia no. 4, Instituto Mexicano del Seguro Social, Mexico DF, Mexico)

\begin{abstract}
Follicle-stimulating hormone (FSH) is synthesized by the anterior pituitary gland in multiple molecular forms. Increased acidic/sialylated FSH charge isoforms are associated with conditions characterized by a low oestrogen output. In the present study, we analysed the dynamics of the changes in mRNA levels of the enzyme Gal $\beta 1,3[4] \mathrm{GlcNAc} \alpha 2,3-$ sialyltransferase (2,3-STase) (one of the enzymes that incorporate sialic acid residues into the FSH molecule) in intact and ovariectomized rats. The anterior pituitaries of 4-day regularly cyclic adult female Wistar rats were obtained at $1000 \mathrm{~h}$ on the days of pro-oestrus $(\mathrm{P})$, oestrus $(\mathrm{O})$, dioestrus 1 (D1) and dioestrus 2 (D2), at $0200 \mathrm{~h}, 1400 \mathrm{~h}, 1800 \mathrm{~h}$ and $2200 \mathrm{~h}$ on D1, at $1800 \mathrm{~h}$ on day of $\mathrm{O}$ and at $1000 \mathrm{~h}$ after 7, 14, 21, 28 and 45 days of oophorectomy performed on the morning of P. Total RNA was isolated from each gland and the 2,3-STase levels were measured by Northern blot hybridization analysis employing a 346-base pair cDNA probe encoding for a non-conserved amino acid sequence of the catalytic domain of the enzyme. Maximal levels of the enzyme mRNA were detected at $1000 \mathrm{~h}$ on D1; thereafter, they progressively decreased by $60 \%$ during the ensuing $24 \mathrm{~h}$, reaching the lowest concentration values ( $26 \%$ of the maximally observed level on D1) at $1000 \mathrm{~h}$ on day of $\mathrm{P}$ and remaining unchanged during
\end{abstract}

the morning of $\mathrm{O}$. Administration of the potent oestradiol receptor antagonist ICI 182,780 at $1000 \mathrm{~h}$ on D1 completely reverted the time-dependent decrease in 2,3-STase mRNA levels observed during the afternoon of D1, whereas oestradiol benzoate administered at $1000 \mathrm{~h}$ on day of $\mathrm{O}$ significantly reduced the enzyme mRNA levels (to $21 \%$ of the levels detected in vehicle-treated controls). In ovariectomized rats, the $\alpha 2,3-\mathrm{ST}$ Tase mRNA progressively increased from day 21 to day 45 post castration. Administration of oestradiol benzoate on day 28 after oophorectomy significantly reduced the 2,3-STase mRNA levels (to $36 \%$ of the levels detected in vehicle-injected controls); ICI 182,780 partially counteracted this oestradiol-mediated effect. The dynamics of these changes in 2,3-STase mRNA levels partially correlated with changes in the relative abundance of the FSH charge isoforms separated by preparative chromatofocusing of anterior pituitary extracts, particularly in glands obtained during the morning of $\mathrm{P}$ and $\mathrm{O}$. These data demonstrate for the first time that pituitary 2,3-STase is a hormonallyregulated enzyme and that the changes in transcription and/or stability of its mRNA may be involved, in part, in the post-translational processing of the FSH molecule during certain physiological conditions. Fournal of Molecular Endocrinology (1999) 23, 153-165

\section{INTRODUCTION}

Follicle-stimulating hormone (FSH), one of the signals produced by the anterior pituitary (AP) gland, is involved in the regulation of several essential reproductive processes occurring at the gonadal level. This gonadotrophin is a heterodimer composed of two glycosylated subunits, $\alpha$ and $\beta$ 
(Pierce \& Parsons 1981, Gharib et al. 1990). Each subunit of FSH exhibits two N-linked glycosylation sites located at positions Asn52 or 56 and Asn78 or 82 in FSH $\alpha$ and Asn6, 7 or 13 and Asn23, 24 or 30 in FSH $\beta$ (Fiddes \& Goodman 1979, Pierce \& Parsons 1981, Esch et al. 1986, Watkins et al. 1987, Gharib et al. 1989). Glycosylation and processing of incorporated oligosaccharides involve a complex biosynthetic pathway which, after initiation in the rough endoplasmic reticulum, continues through the Golgi apparatus until the mature gonadotrophin is transported to secretory granules (Baenziger \& Green 1988). As in other related glycoprotein hormones (luteinizing hormone $(\mathrm{LH})$, chorionic gonadotrophin and thyrotrophin (TSH)), oligosaccharide structures on FSH are highly variable and play a key role in determining the biological properties of the hormone (Wilson et al. 1990, Ulloa-Aguirre et al. 1995, Ulloa-Aguirre \& Timossi 1998). In FSH, most oligosaccharide chains are dibranched structures with either both ends terminating in a negatively charged group (GalNAc-SO ${ }_{4}{ }^{-}$or Gal-sialic acid) or one branch terminating in a negatively charged residue and the other in noncharged mannose. Dibranched oligosaccharides, with and without a bisecting GlcNAc moiety linked to the $\beta$-linked core mannose residues, and tribranched oligosaccharides of different types, but containing terminal sialic acid residues are also found (Green \& Baenziger 1988, Stockell Hartree \& Renwich 1992). Variations in the structure and distribution of sialylated and, to a lesser extent, sulphated Asn-linked oligosaccharides constitute the main chemical basis for FSH isoform formation and the extensive charge heterogeneity exhibited by this particular gonadotrophin (Ulloa-Aguirre et al. 1995).

Multiple FSH charge isoforms have been isolated from AP extracts, serum and urine of several animal species including man (Chappel et al. 1983, Ulloa-Aguirre et al. 1986, 1988, 1992a, 1995, Simoni et al. 1994, Stanton et al. 1996). The more acidic/sialylated variants exhibit longer plasma half-life but lower receptor binding activity and in vitro biological potency than the less acidic counterparts (Ulloa-Aguirre et al. 1984, 1992a, Cerpa-Poljak et al. 1993, Zambrano et al. 1996). The distribution of the intrapituitary and secreted FSH charge isoforms changes during specific physiological conditions (Padmanabhan et al. 1988, Wide 1989, Wide \& Bakos 1993, Ulloa-Aguirre et al. 1995, Zambrano et al. 1995), thus indicating that FSH heterogeneity is a hormonally regulated phenomenon. In terms of endocrine regulation, there is growing evidence suggesting that hypothalamic and gonadal inputs (gonadotrophin- releasing hormone (GnRH) and/or sex steroids) may be involved in modulating the molecular nature of the hormone and therefore its biological attributes (Ulloa-Aguirre et al. 1995). For example, it has been shown that the release of less sialylated, short-lived FSH glycoforms is increased in conditions in which the AP is exposed to high levels of oestrogens such as the periovulatory phase of the menstrual cycle or after long-term oestradiol administration to hypogonadal subjects (Galle et al. 1983, Padmanabhan et al. 1988, Wide \& Bakos 1993, Wide \& Naessén 1994, Zambrano et al. 1995). However, the molecular mechanisms responsible for the changes in sialylation of the FSH molecule during these and other physiological states remain unclear. Since the oestrous cycle represents an ordered sequence of changing hormonal events during which the pituitary gland is cyclically exposed to variable amounts of gonadal and hypothalamic hormones, we tested the hypothesis that the mRNA levels of rat Gal $\beta 1,3 \mathrm{GlcNAc}$ $\alpha 2,3$-sialyltransferase (2,3-STase) (the enzyme that forms the NeuAc $\alpha 2,3 \mathrm{Gal} \beta 1,3 \mathrm{GlcNAc}$ sequence typically found to terminate complex type $\mathrm{N}$-linked oligosaccharide chains such as those present in FSH (Weinstein et al. 1982, Baenziger \& Green 1988, Kleen \& Berger 1993)) changes during the oestrous cycle and that oestrogens play a key role in the regulation of this enzyme mRNA levels.

\section{MATERIALS AND METHODS}

Adult Wistar female rats were maintained in groups of 5 animals under light-controlled conditions (lights on from 0500 to $1900 \mathrm{~h}$ ). The body weights of the rats were between 250 and $300 \mathrm{~g}$. Daily vaginal smears were obtained between $0900 \mathrm{~h}$ and $1100 \mathrm{~h}$, and no animal was used until it had shown at least three consecutive 4-day oestrous cycles. Rats were decapitated at $1000 \mathrm{~h}$ on the days of pro-oestrus (P), oestrus (O), dioestrus 1 (D1) and dioestrus 2 (D2), at $0200 \mathrm{~h}, 1400 \mathrm{~h}, 1800 \mathrm{~h}$ and $2200 \mathrm{~h}$ on D1, at $1800 \mathrm{~h}$ on the day of $\mathrm{O}$ and at $1000 \mathrm{~h}$ after $7,14,21,28$ and 45 days of oophorectomy performed on the morning of $\mathrm{P}$. The anterior pituitaries were dissected free from the posterior pituitaries, rapidly removed and immediately frozen at $-70^{\circ} \mathrm{C}$ until extraction of total cytoplasmic RNA or soluble proteins.

\section{RNA extraction and Northern blot hybridization analysis}

Total RNA from rat brain and anterior pituitary glands was isolated by the single-step acid 


\section{CYTOPLASM GOLGI}
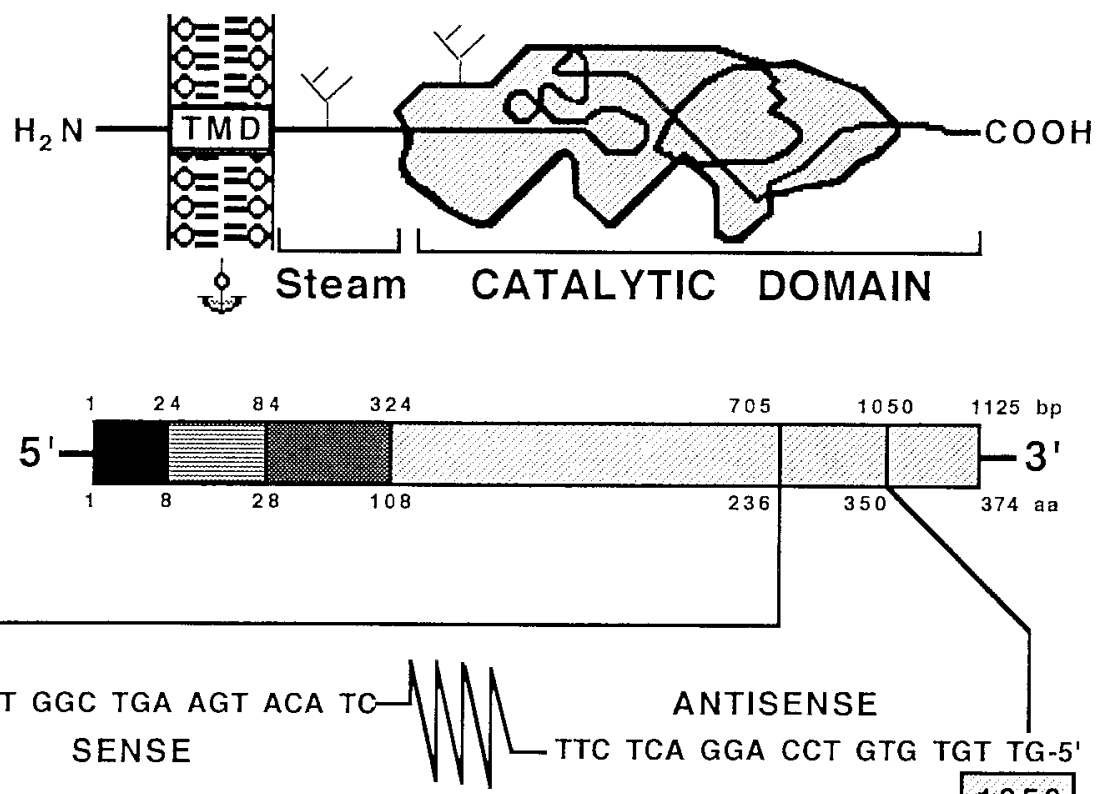

704

$346 \mathrm{bp}$

\section{RT / PCR PRODUCT}

FIGURE 1. (Top panel) Model for the domain structure and putative topology of the $\alpha 2,3-$ STase in the Golgi membrane (TMD, transmembrane domain; branched structures, putative glycosylation sites). (Middle panel) Representation of the enzyme according to the model shown on top. Straight lines indicate the untranslated parts of the mRNA/cDNA and the differently filled boxes represent the sequences coding for the corresponding domains shown in the top figure; numbers indicate the length of the different regions (bp, base pairs; aa, amino acids). (Bottom panel) Sequence of the 2,3-STase cDNA synthesized and employed in the present study; filled boxes show the limits of the cDNA sequence.

guanidinium thiocyanate/phenol/chloroform extraction method (Chomczynski \& Sacchi 1987) using the TRIZol reagent (Gibco, Gaithersburg, MD, USA) and following the instructions supplied by the manufacturer. For Northern blot hybridization analysis, total RNA $(\sim 15 \mu \mathrm{g})$ was fractionated on $1.0 \%$ denaturating agarose gel and transferred to Zeta Probe GT membranes (BioRad, Hercules, CA, USA). After UV crosslinking and prehybridization, the membranes were hybridized during 16-24 h at $65{ }^{\circ} \mathrm{C}$ with the 2,3-STase cDNA probe radiolabelled with ${ }^{32} \mathrm{P}$ using a random primer labelling kit (Gibco). The filters were then washed at high stringency and autoradiographed on X-OMAT-AR film (Eastman Kodak). Each blot was stripped and rehybridized with a rat cyclophilin (Cyc) cDNA probe, prepared by random priming and used as a control to compare the amounts of RNA loaded and transferred. Semiquantitative analysis of specific 2,3-STase mRNA was performed by densitometric scanning of the autoradiograms employing an Eagle Eye II video imaging system (Stratagene, La Jolla, CA, USA). Results are expressed as the 2,3-STase/ Cyc mRNAs relative optical density (O.D.) ratios.

\section{Synthesis and amplification of rat $\alpha 2,3-S T a s e$ cDNA}

Like other glycosyltransferases bearing type II membrane topology, the 2,3-STase has a short cytoplasmic domain, a hydrophobic signal-anchor sequence, a luminal stem region not required for catalytic activity and a large luminal catalytic domain (Kleen \& Berger 1993) (Fig. 1). For the 
purpose of this study, we synthesized a cDNA probe of $346 \mathrm{bp}$ encoding for a non-conserved amino acid sequence (residues 236 to 350 ) of the catalytic domain of the enzyme located 10 amino acid residues far from the carboxyl-end of the so-called sialylmotif region (residues 178-225) (Wen et al. 1992, Datta \& Paulson 1995). The oligonucleotide primers employed for the construction and amplification of cDNA by reverse transcription-polymerase chain reaction (RT-PCR) were chosen based on the 2,3-STase cDNA sequence reported by Wen et al. (1992); sequences of the corresponding sense and antisense oligonucleotides are shown in Fig. 1. Reverse transcription of poly $(\mathrm{A})+$ RNA extracted from female rat brain (which expresses 2,3-STase mRNA at relatively high levels (Wen et al. 1992, Kitagawa \& Paulson 1994)) was performed employing the GeneAmp RNA PCR reagent kit (Perkin Elmer, Foster City, CA, USA) following the instructions of the manufacturer. After completion of the reverse transcription, PCR was initiated by adding $80 \mu \mathrm{l}$ of a mix containing 2.5 units AmpliTaq DNA polymerase (Perkin Elmer), $15 \mathrm{mM}$ of the sense and antisense oligonucleotides, $2 \mathrm{mM} \mathrm{MgCl}_{2}$ and $8 \mu \mathrm{l}$ $10 \times$ PCR buffer II (Perkin Elmer). The temperature was raised to $95{ }^{\circ} \mathrm{C}$ for $105 \mathrm{~s}$ and the amplification was carried out by cycling 35 times, $30 \mathrm{~s}$ at $95^{\circ} \mathrm{C}, 30 \mathrm{~s}$ at $60^{\circ} \mathrm{C}$ and $1 \mathrm{~min}$ at $72{ }^{\circ} \mathrm{C}$, and ended with a final extension step of $7 \mathrm{~min}$ at $72{ }^{\circ} \mathrm{C}$. The $346 \mathrm{bp}$ cDNA fragment was isolated by agarose gel electrophoresis followed by purification in polyester plug spin inserts (Glenn \& Glenn 1994) and ethanol precipitation, and then subcloned into the pCR-Script SK (+) cloning vector (Stratagene). The sequence of the cDNA fragment was confirmed by dideoxynucleotide sequencing (Sanger et al. 1977). Northern blots of total RNA from different tissues probed with the 2,3-STase $\mathrm{cDNA}_{704-1050}$ showed probe hybridization to a mRNA of $\sim 2.5 \mathrm{~kb}$ only in those tissues previously reported to express this particular enzyme (Wen et al. 1992). The relative amounts of $\alpha 2,3-\mathrm{ST}$ Tase $\mathrm{mRNA}$ detected in pituitary glands from castrated or D1 rats employing this particular cDNA probe represented $\sim 39 \%$ of those present in other rat tissues that express this particular mRNA at high levels (i.e. lung, heart, brain, kidney).

\section{Chromatofocusing of anterior pituitary extracts}

AP glands were individually homogenized at $4{ }^{\circ} \mathrm{C}$ with ten strokes of a Teflon pestle in $100 \mu \mathrm{l}$ chromatofocusing eluent buffer (1:8 dilution of Polybuffer 74 (Pharmacia Fine Chemicals,
Piscataway, NJ, USA) in deionized water, $\mathrm{pH} 4 \cdot 0$ ) containing the protease inhibitor phenylmethylsulphonylfluoride $(0.2 \mathrm{mg} / \mathrm{ml}$; Sigma, St Louis, MO, USA). The AP homogenate was centrifuged at $1000 \mathrm{~g}$ for $30 \mathrm{~min}$ at $4{ }^{\circ} \mathrm{C}$, and the supernatant fraction (AP extract) removed and stored frozen at $-20{ }^{\circ} \mathrm{C}$. Groups of four AP extracts were separately chromatofocused in $30 \times 1 \mathrm{~cm}$ columns of PBE-94 (Pharmacia) following a chromatofocusing procedure previously described (Ulloa-Aguirre et al. 1992a). After measuring the $\mathrm{pH}$ of the eluent fractions (110 to $1302-\mathrm{ml}$ fractions/column), they were stored frozen at $-20{ }^{\circ} \mathrm{C}$ until the day of radioimmunoassay (RIA) of FSH. A total of three or four AP extracts per animal group were pooled and chromatofocused separately in triplicate columns. Recoveries of FSH by this method were $76 \pm 4 \%$ of the total amount originally applied to the column.

\section{RIA of FSH and oestradiol}

Purified rat FSH-I-7 (NIADDK, Bethesda, MD, USA) was iodinated by the Chloramine $\mathrm{T}$ method. The RIA of FSH was performed using the rat RIA kit provided by the NIADDK as previously reported (Ulloa-Aguirre et al. 1988); the reference preparation employed was rat FSH-RP-2 (NIADDK). To avoid interassay variations, all samples from a single column were included in the same batch. Intra-assay variability for this RIA system was $7 \%$ and the sensitivity was $0.1 \mathrm{ng} / \mathrm{ml}$. The RIA of $17 \beta$-oestradiol was performed employing a solid phase commercial reagent kit (Diagnostic Products Corporation, Los Angeles, CA, USA). All samples were analysed in a single RIA run; the intra-assay variability was $3 \%$ and the sensitivity was $4 \mathrm{pg} / \mathrm{ml}$.

\section{Statistical analysis}

One-way analysis of variance and the unpaired $t$-test were used to analyse differences between groups.

\section{RESULTS}

Adult cyclic rats were killed at the times shown in Fig. 2 and total pituitary RNA was analysed for the presence of 2,3-STase mRNA. As shown in the figure, the mRNA of the enzyme changed according to the day and time of the oestrous cycle. The highest levels were recorded on the morning of D1, whereas the lowest were on the morning of the days of $\mathrm{P}$ and $\mathrm{O}$. A progressive increase in the 

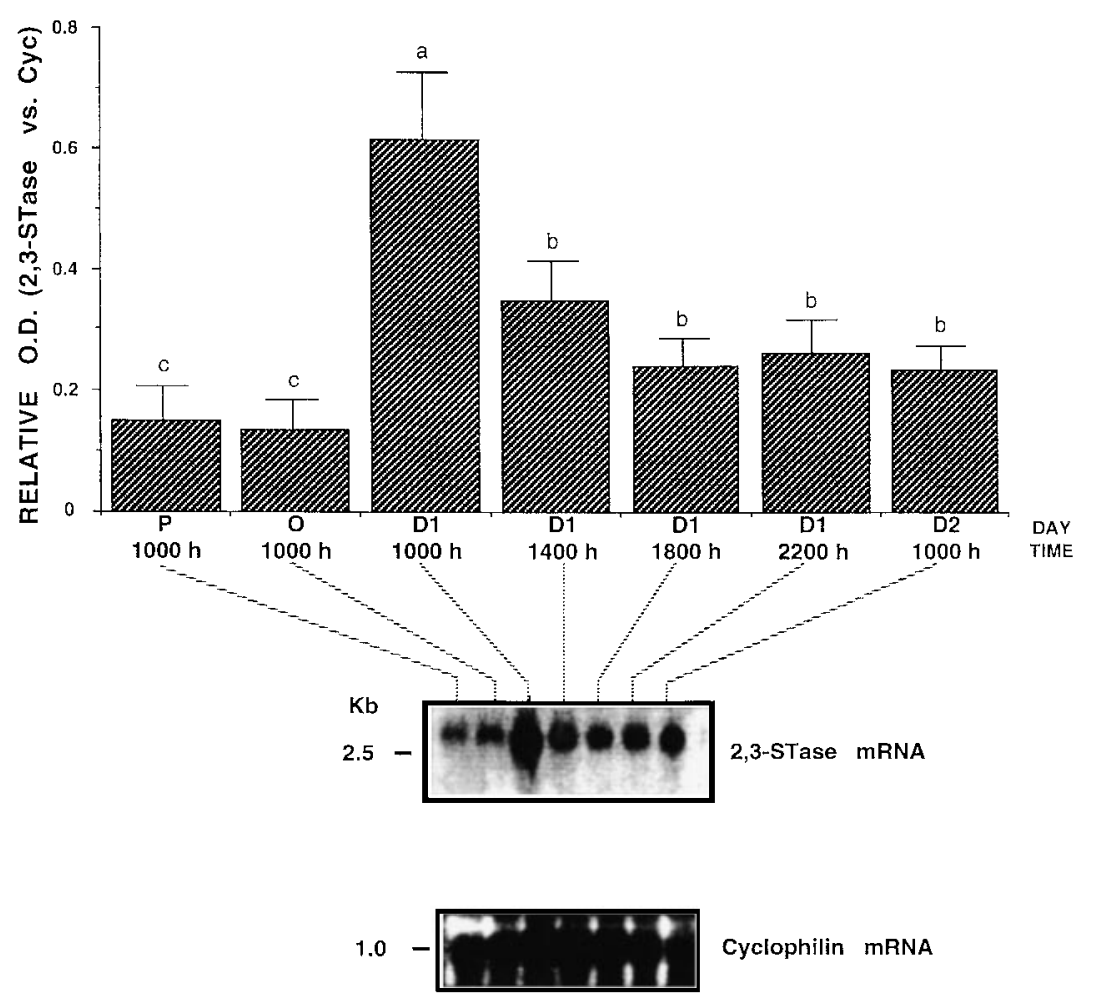

FIGURE 2. Representative experiment showing the changes in anterior pituitary 2,3-STase mRNA levels throughout the rat oestrous cycle (means \pm s.D. of 3 to 5 animals per group). Different letters above the bars indicate the existence of significant $(P<0 \cdot 05)$ differences between each group. Also shown are representative Northern blots of total RNA from anterior pituitary glands probed with radiolabelled 2,3-STase and cyclophilin cDNA probes. Similar results were found in three additional experiments.

enzyme mRNA levels was observed at $1800 \mathrm{~h}$ on the day of $\mathrm{O}$ and at $0200 \mathrm{~h}$ on D1 (not shown). With castration on the morning of the day of $\mathrm{P}$, the AP $\alpha 2,3-S T a s e$ mRNA levels remained at the values found on day of $\mathrm{P}$ until day 21 post castration, when the enzyme mRNA levels showed a progressive increase reaching maximal values after day 28 post-oophorectomy (Fig. 3).

Based on the results of the time course study, the effects of oestradiol administration on the pituitary $\alpha 2,3-\mathrm{ST}$ Tase mRNA levels were then tested. For this purpose, animals were subcutaneously injected with either vehicle (corn oil) or $10 \mu \mathrm{g}$ oestradiol benzoate (OB) on the morning of the day of $\mathrm{O}$ and total AP RNA was thereafter obtained at $1000 \mathrm{~h}$ on the presumptive D1. In a separate experiment, D1 animals received at $1000 \mathrm{~h} 2 \mathrm{mg} / \mathrm{kg}$ body weight (b.w.) of the potent oestrogen receptor antagonist ICI 182,780 (Wakeling et al. 1991) and its effects on 2,3-STase mRNA levels were then examined eight and twenty-four hours after its administration. As shown in Fig. 4, administration of $\mathrm{OB}$ resulted in a significant decrease in the 2,3-STase mRNA to levels similar to those detected during the morning of $\mathrm{O}$. In contrast, administration of a single dose of ICI 182,780 at $1000 \mathrm{~h}$ on D1 completely reversed the naturally occurring, time-dependent decrease in 2,3-STase mRNA levels observed at $1800 \mathrm{~h}$ on D1 and partially (by $30 \pm 5 \%$ ) that occurring at $1000 \mathrm{~h}$ on D2 (Fig. 5). Castrated rats also received one dose of $10 \mu \mathrm{g}$ OB or vehicle on day 28 after oophorectomy and the levels of 2,3-STase mRNA were analysed $24 \mathrm{~h}$ and $48 \mathrm{~h}$ after $\mathrm{OB}$ administration. As shown in Fig. 6, oestradiol administration to female castrates significantly reduced the levels of the enzyme mRNA, although to a lesser extent than in OB-treated intact animals (to $56 \cdot 4 \pm 5 \cdot 7 \%$ and $36 \cdot 8 \pm 7 \cdot 8 \%$ of the levels detected $24 \mathrm{~h}$ and $48 \mathrm{~h}$ after $\mathrm{OB}$ administration in vehicle-injected castrated controls respectively). In this animal group, administration of ICI 182,780 and oestradiol benzoate, in tandem, reversed by $36 \%$ the effects of 

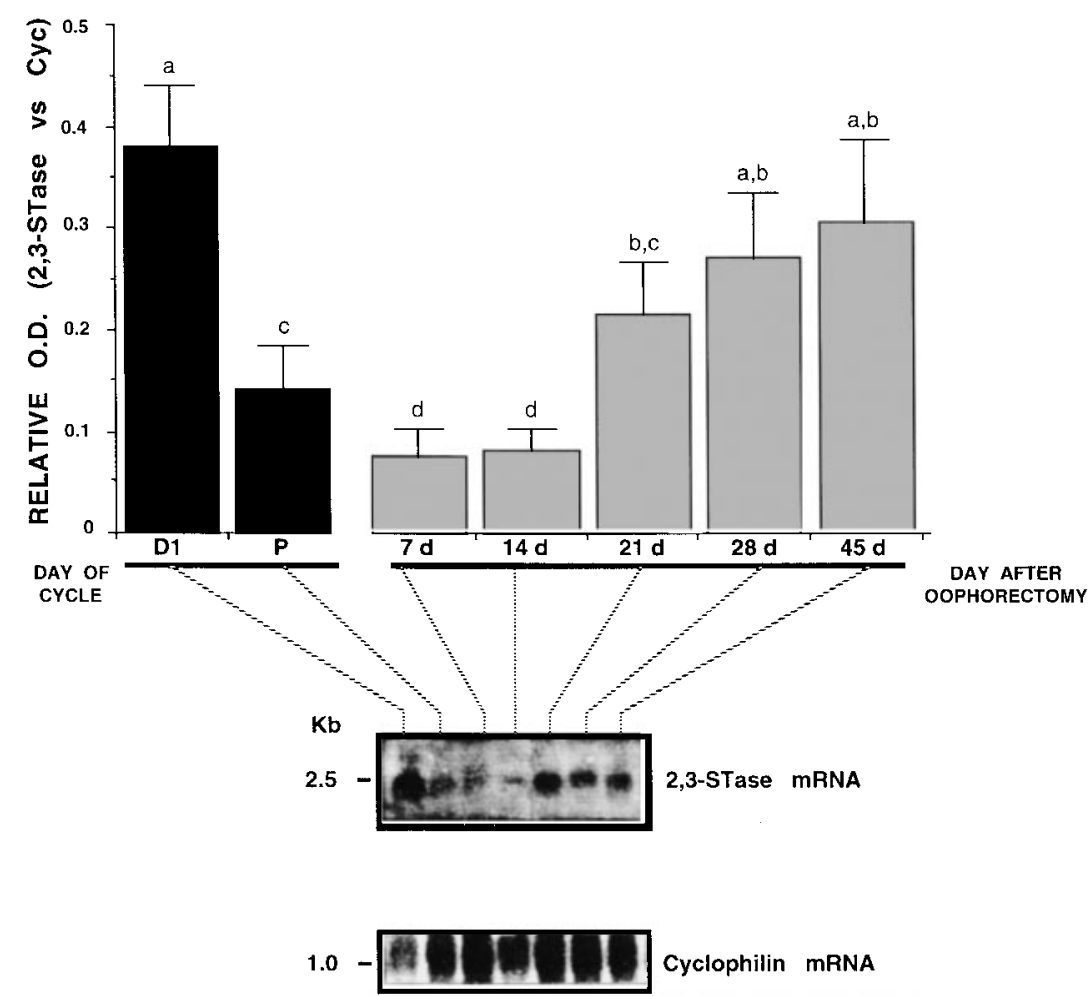

FIGURE 3. Changes in anterior pituitary 2,3-STase mRNA levels before and after castration on the morning of the day of $\mathrm{P}$ (means \pm s.D.). Different letters above the bars indicate the existence of significant $(P<0 \cdot 05)$ differences between each group. Also shown are representative Northern blots of total RNA from anterior pituitary glands probed with radiolabelled 2,3-STase and cyclophilin cDNA probes. The results are representative of 3 independent experiments.

OB on 2,3-STase mRNA levels observed at $48 \mathrm{~h}$ (Fig. 7).

Chromatofocusing fractionation of AP extracts revealed a marked increase in the relative abundance of FSH charge isoforms with elution $\mathrm{pH}$ values $\geq 5.0$ at the time of highest serum oestradiol concentrations and lowest 2,3-STase mRNA levels, i.e. on the morning of $\mathrm{P}$ (Fig. 8). These less acidic $\mathrm{FSH}$ isoforms remained relatively increased during the day of $\mathrm{O}$ in a setting of low enzyme mRNA and relatively decreased serum oestradiol levels. Finally, on the morning of $\mathrm{D} 2$, there was a dissociation between the enzyme mRNA and serum oestradiol levels and the charge distribution of AP FSH, with the highest values for the most acidic isoforms in a setting of moderately increased serum oestradiol and decreased levels of the 2,3-STase mRNA (Fig. 8). In castrated rats, the $\mathrm{pH}$ distribution pattern of AP FSH was similar to that exhibited by intact animals killed at $1000 \mathrm{~h}$ on D1, with $>80 \%$ of total $\mathrm{FSH}$ recovered in elution $\mathrm{pH}$ values $<5 \cdot 0$; a modest and not significant increase in less acidic isoforms (elution $\mathrm{pH}$ values $\geq 5 \cdot 0$ ) was detected exclusively on day 28 post-oophorectomy (not shown).

\section{DISCUSSION}

In the present study, we found that the mRNA levels of the 2,3-STase, one of the enzymes that add sialic acid to $\mathrm{FSH}$, varied significantly according to the time and day of the rat oestrous cycle and that the dynamics of these changes in the enzyme mRNA levels were temporally associated with variations in serum oestradiol concentrations. Specifically, during the preovulatory days (D2 and $\mathrm{P}$ days) we observed a progresive decrease in 2,3-STase mRNA levels in the face of increasing serum oestradiol concentrations, reaching its lowest values immediately before and after maximal pituitary exposure to this sex steroid, i.e. in the 


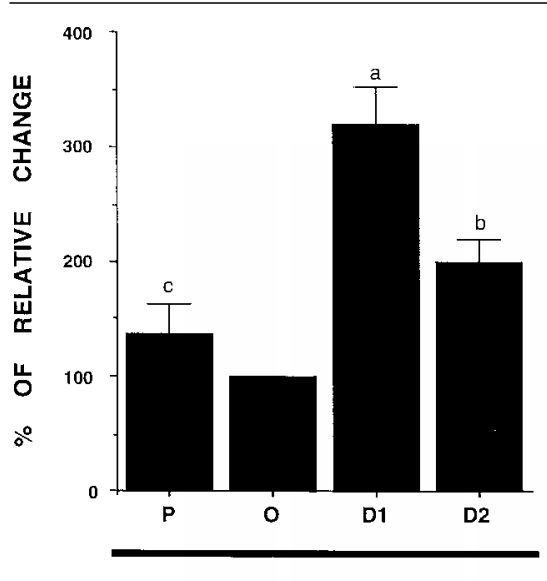

DAY OF CYCLE

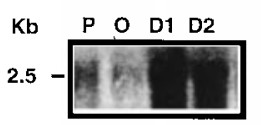

Vh OB

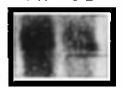

2,3-STase mRNA
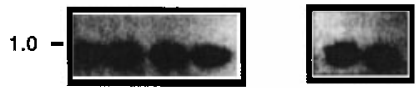

Cyclophilin mRNA

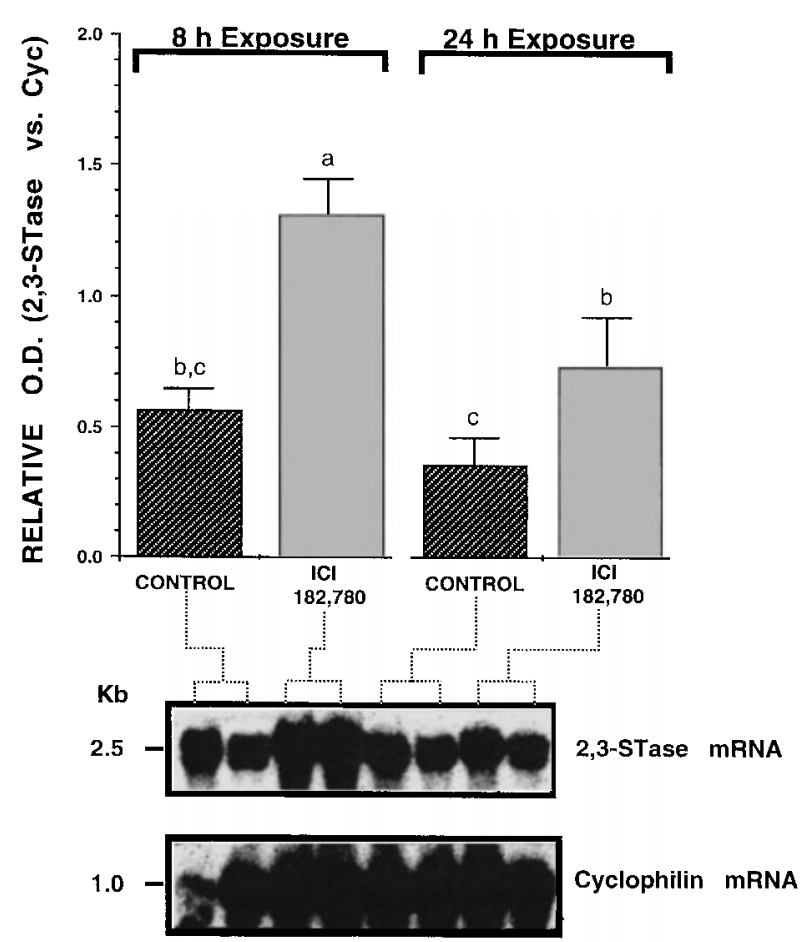

FIGURE 5. 2,3-STase mRNA levels in intact rats exposed during $8 \mathrm{~h}$ and $24 \mathrm{~h}$ to either vehicle (control) or the anti-oestrogen ICI 182,780 (2 mg/kg b.w.) administered subcutaneously at $1000 \mathrm{~h}$ on D1 (means \pm s.D.). Different letters above the bars indicate the existence of significant $(P<0 \cdot 05)$ differences between each group. Representative Northern blots of total RNA from anterior pituitary glands probed with radiolabelled 2,3-STase and cyclophilin cDNA probes are also shown. The results are representative of 3 separate experiments.

or even days after maximal oestradiol exposure as disclosed by the persistently low 2,3-STase mRNA levels during the morning of $\mathrm{O}$ and after gonadal removal on the day of $\mathrm{P}$. Nevertheless, the finding that the $\alpha 2,3$-STase mRNA levels remained persistently low at least for 14 days following oophorectomy, and that the response to both oestradiol benzoate and ICI 182,780 in the gonadectomized group was considerably attenuated as compared with those exhibited by the intact animals, suggests that other extrapituitary factors may be additionally involved in the control of this enzyme mRNA levels (see below).

We and others have shown that sialic acid plays a key role in determining both the charge isoform distribution and the biological activity of $\mathrm{FSH}$ and other glycoprotein hormones (Reichert 1971, Ulloa-Aguirre et al. 1984, Chappel et al. 1982, 1984, Wide 1989, Schaaf et al. 1997). Incubation of rat 


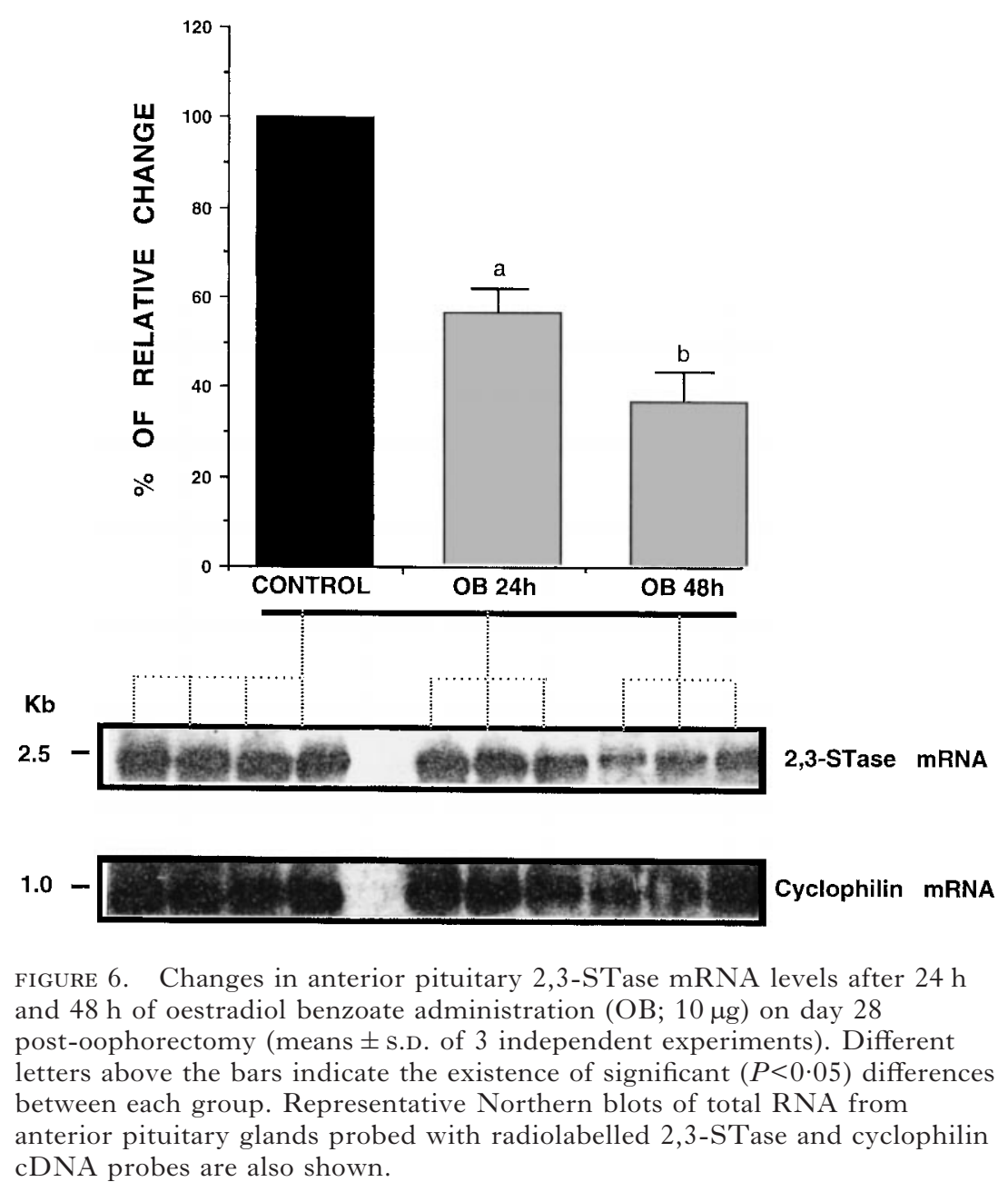

and monkey AP extracts and recombinant human FSH with the enzyme neuraminidase progressively decreased the most acidic components of the hormone while concomitantly increasing the proportion of less acidic forms until only $\mathrm{FSH}$ isoforms with elution $\mathrm{pH}$ values of 6.4 or greater were detected (Chappel et al. 1984, Ulloa-Aguirre et al. 1984, Galway et al. 1990). Studies with neuraminidase-treated human sera and pituitary extracts also demonstrated that removal of sialic acid residues induces a shift in the charge of FSH isoforms towards less acidic isomers, thus suggesting that some of the charge variations detected in different physiological conditions are mainly due to differences in the terminal sugar content of FSH (Wide 1982, 1985, 1989). In the present study, chromatofocusing fractionation of AP extracts allowed the identification of significant shifts in FSH charge isoform distribution throughout the cycle, with a significant increase in the relative abundance of the less acidic FSH isoforms during the morning of the day of $\mathrm{P}$ and to a lesser extent during $\mathrm{O}$, times at which low 2,3-STase mRNA levels were detected. However, such a close inverse relationship between the abundance of less acidic isoforms and enzyme mRNA levels was practically absent during the following days of the cycle, particularly on D2, as well as after 7 and 14 days of castration, conditions during which the highest relative abundance of more acidic isoforms was detected in a setting of significantly decreased 2,3-STase mRNA levels. The existence of a partial rather than a complete correlation between this enzyme mRNA levels and the changes in FSH charge isoform distribution may be due to the following: (1) the concomitant participation of other sialyltransferases (e.g. $\alpha 2,6$-STase) or glycosyltransferases (which may in turn be regulated by one or several extrapituitary factors) in FSH processing, including sialylation and/or sulphation (Baenziger \& 


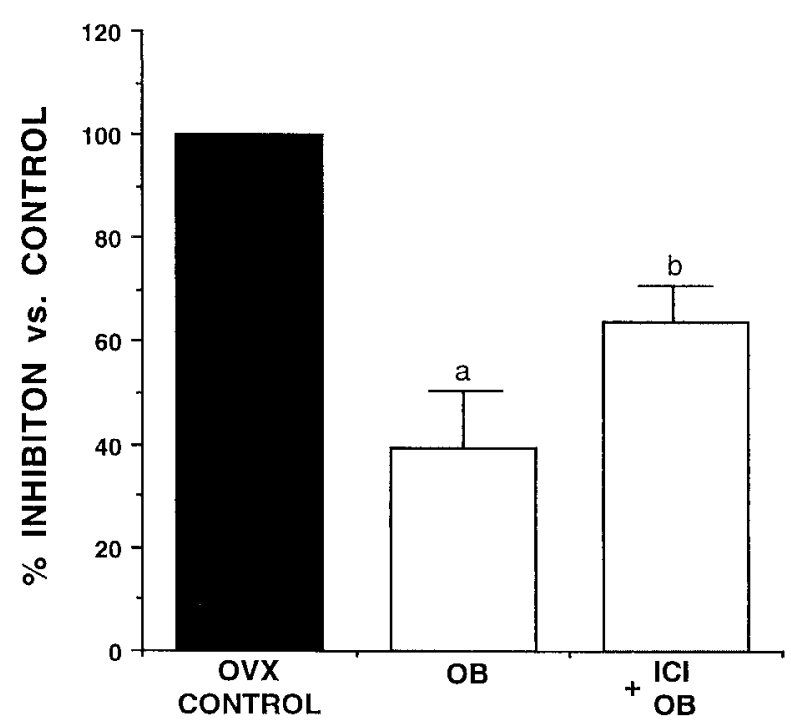

FIGURE 7. The effects of oestradiol benzoate (OB) or ICI 182,780 (ICI) plus OB on 2,3-STase mRNA levels in oophorectomized rats (means \pm S.D. of three separate experiments). Groups of four rats were castrated on the morning of P. On day 28 after oophorectomy, animals were divided into three treatment groups. The control group received vehicle at all times; the OB group was treated with vehicle at $1000 \mathrm{~h}$, OB $(10 \mu \mathrm{g}$ subcutaneously) at $1100 \mathrm{~h}$ and again with vehicle at $1000 \mathrm{~h}$ on the next day. Finally, the ICI 182,780 group received $2 \mathrm{mg} / \mathrm{kg}$ b.w. of the anti-oestrogen at $1000 \mathrm{~h}$, followed by $\mathrm{OB}$ at $1100 \mathrm{~h}$ and again ICI 182,780 at $1000 \mathrm{~h}$ on the next day. All animals were killed by decapitation $48 \mathrm{~h}$ after the start of the experiment and the pituitary glands were processed for 2,3-STase mRNA measurement as described in Materials and Methods. Results are expressed as percentage change considering the normalized O.D. in the control group as $100 \%$. Different letters above the bars indicate the existence of significant $(P<0 \cdot 05)$ differences between each group.

Green 1988, Darmesh \& Baenziger 1993, Helton \& Magner 1994a,b, Kitagawa \& Paulson 1994, Rafferty et al. 1995); (2) to variations in substrate availability, which may eventually allow for effective sialylation in conditions characterized by low enzyme levels and reduced FSH production, such as those present during both dioestrous days (Smith et al. 1975, Ortolano et al. 1988, present study); (3) to oestrogen-independent variations in the half-life of the enzyme, and/or (4) to the inability of our FSH RIA system to allow for a clear distinction between increased production of more acidic/ sialylated isoforms and decreased immunogenicity of epitopes present in certain FSH glycoforms bearing less complex oligosaccharide structures and whose relative abundance may be increased at a given time (Dahl \& Stone 1992, Stanton et al. 1996).

These and other previously reported in vivo experiments (Padmanabhan et al. 1988, Wide \& Naessén 1994) do not clarify unambiguously whether oestradiol modifies 2,3-STase mRNA levels and thus protein sialylation directly on the pituitary gland, on the hypothalamus to regulate GnRH activity, or by a combination of several pathways. Although some studies strongly implicate $\mathrm{GnRH}$ in modulating the glycosylation and degree of sialic acid-dependent charge heterogeneity of LH and FSH respectively (Galle et al. 1983, Miller et al. 1983, Liu et al. 1992, 1994, Ulloa-Aguirre et al. 1992b), more recently, several in vivo studies involving experimental animals and humans have allowed us to distinguish between pituitary and hypothalamic sites of regulation by oestrogens. Using the nutritionally growth-restricted ovariectomized lamb as the experimental model (state of hypogonadotrophism due to central inhibition of GnRH secretion in which the pituitary responsiveness to exogenous GnRH is preserved (Ebling et al. 1990)) it has been shown that whereas pulsatile administration of $\mathrm{GnRH}$ failed to alter the pattern of charge isoform distribution of intrapituitary and secreted FSH, oestradiol treatment selectively increased the secretion of less acidic/sialylated isoforms (Hassing et al. 1993, Lee et al. 1998). Likewise, although in normally ovulating women the relative abundance of less acidic $\mathrm{FSH}$ isoforms increased dramatically during the periovulatory period (a time of increased oestradiol levels and pituitary GnRH sensitivity) (Padmanabhan et al. 1988, Wide \& Bakos 1993, Zambrano et al. 1995), the changes observed in the distribution of more and less acidic/sialylated serum FSH isoforms were not significantly altered by the consecutive administration of a low and high GnRH dose during each cycle phase (Zambrano et al. 1995). Although such studies data do not exclude additional intrapituitary loci of control via autocrine and/or paracrine interactions (whose nature and role, if any, in modifying the post-translational molecular forms of FSH are not known), the overall data strongly indicate that oestrogens play a determinant role in defining the degree of glycosylation of the FSH molecule during certain physiological conditions.

The present results are in agreement with other studies showing that products from target glands under the control of the AP gland are tightly involved in the posttranslational processing of the trophic signal (Miura et al. 1989, Gyves et al. 1990, Darmesh \& Baenziger 1993, Helton \& Magner 1994a,b, Persani et al. 1998). In fact, it has 

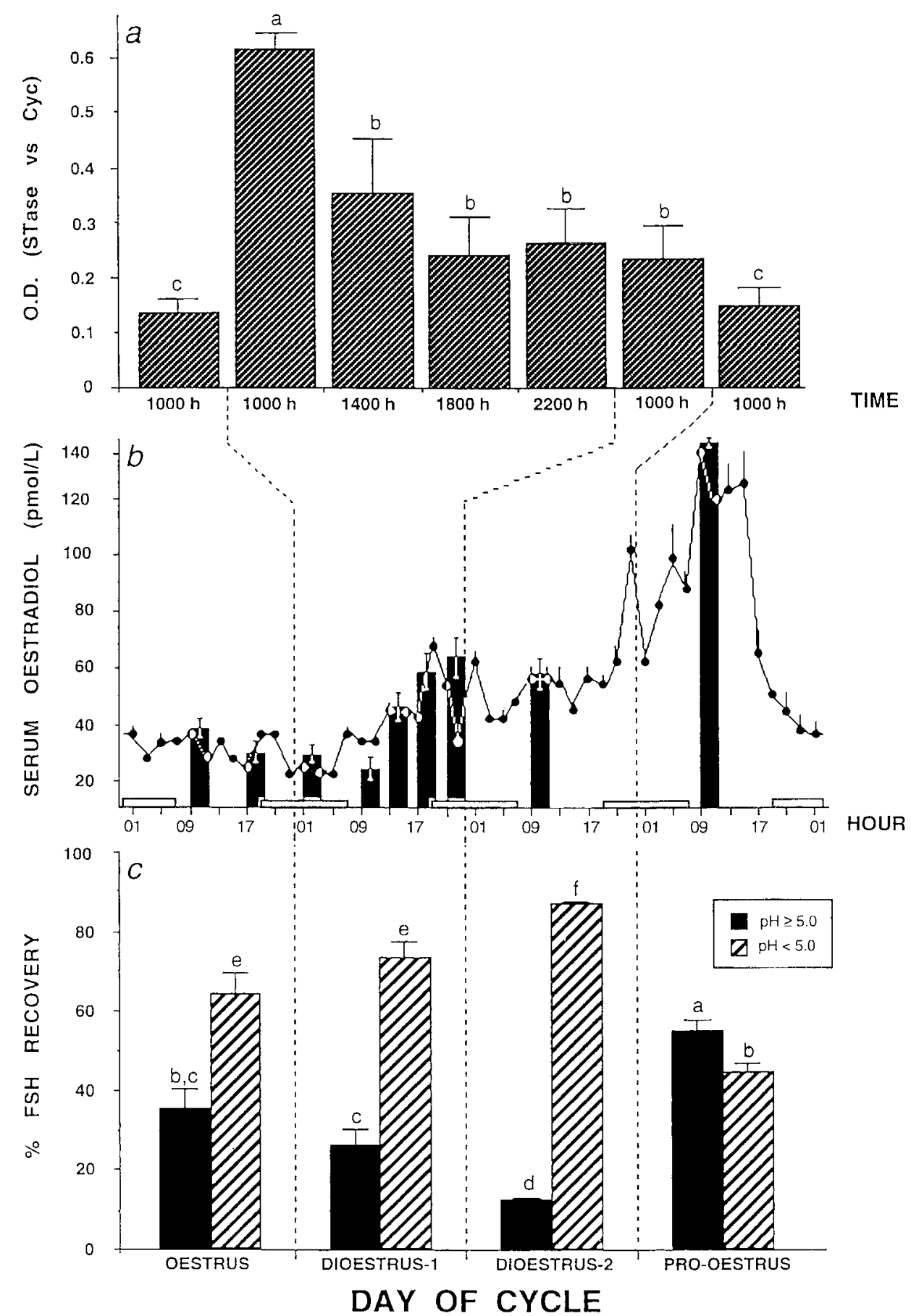

FIGURE 8. Temporal relationship between changes in anterior pituitary 2,3-STase (STase) mRNA levels throughout the oestrous cycle (a), the serum oestradiol concentrations (black bars in (b)) and the charge distribution of pituitary FSH at $1000 \mathrm{~h}$ on each day of the oestrous cycle (c); data in (c) are presented as the proportion of FSH recovered within elution $\mathrm{pH}$ values $\geq 5.0$ and $<5.0$ normalized as a percentage of total FSH recovered from each single chromatofocusing run ( $n=$ three columns per day of cycle). Intrapituitary FSH content was $0 \cdot 15 \pm 0 \cdot 04,0 \cdot 16 \pm 0 \cdot 02$, $0 \cdot 06 \pm 0.01$ and $0 \cdot 08 \pm 0.01 \mu \mathrm{g}$ FSH-RP-2/gland on the days of P, O, D1 and D2 respectively. For each graph the results represent the means \pm S.D. The pattern of oestradiol levels in serum samples taken at frequent intervals throughout the oestrous cycle as reported by Smith et al. (1975) is also shown for comparative purposes (closed circles in (b); means \pm s.E.M.). Horizontal bars represent the dark period. 
been demonstrated that activities of some glycosyltransferases ( $\alpha 2,6$-sialyltransferase and GalNActransferase) and mannosidases ( $\alpha$-mannosidase-II), may be modulated specifically at the pituitary level by thyroid hormones (Helton \& Magner 1994a,b) and oestrogens (Darmesh \& Baenziger 1993), thereby potentially affecting sialylation and sulphation of TSH and LH respectively. Thus, regulation of the structure and biological properties of glycoprotein hormones by specific stimuli may represent an additional level of feedback control by which the target cell regulates the duration and intensity of the trophic signal released from the AP gland.

\section{ACKNOWLEDGEMENTS}

This work was supported by grants from the Consejo Nacional de Ciencia y Tecnología (CONACyT, grants 0004P-N9505 and G016M), the Programa Latinoamericano de Capacitación e Investigación en Reproducción Humana (PLACIRH), the Universidad Autónoma Metropolitana-Iztapalapa, and PADEP-UNAM (500307), México DF. The authors are indebted to the NIADDK for the rat FSH RIA material, to Drs Victor Sales and José Luis Velázquez from Zeneca Farma, Mexico, for the ICI 182,780 and to $\mathrm{Mr}$ Roberto Chavira for performing the RIA of $17 \beta$-oestradiol. Pablo Damián-Matsumura is a postgraduate student from the Facultad de Estudios Profesionales-Zaragoza, Universidad Nacional Autónoma de México, Mexico.

\section{REFERENCES}

Baenziger JU \& Green ED 1988 Pituitary glycoprotein hormone oligosaccharides: structure, synthesis and function of the asparagine-linked oligosaccharides on lutropin, follitropin and thyrotropin. Biochimica et Biophysica Acta 947 287-306.

Cerpa-Poljak A, Bishop LA, Hort YJ, Chin CKH, DeKroon R, Mahler SM, Smith GM, Stuart MC \& Schofield PR 1993 Isoelectric charge of recombinant human follicle-stimulating hormone isoforms determines receptor affinity and in vitro bioactivity. Endocrinology 132 351-356.

Chappel SC, Coutifaris C \& Jacobs SC 1982 Studies on the microheterogeneity of FSH present within the anterior pituitary gland of ovariectomized hamsters. Endocrinology 110 847-854.

Chappel SC, Ulloa-Aguirre A \& Coutifaris C 1983 Biosynthesis and secretion of follicle-stimulating hormone. Endocrine Reviews 4 179-211.

Chappel SC, Bethea CL \& Spies HG 1984 Existence of multiple forms of follicle-stimulating hormone within the anterior pituitaries of Cynomolgus monkeys. Endocrinology $115452-461$.
Chomczynski P \& Sacchi N 1987 Single-step method of RNA isolation by acid guanidinium thiocyanate-phenol-chloroform extraction. Analytical Biochemistry 162 156-159.

Dahl KD \& Stone MP 1992 FSH isoforms, radioimmunoassays, bioassays, and their significance. Fournal of Andrology 13 11-22.

Darmesh SM \& Baenziger JU 1993 Estrogen modulates expression of the glycosyltransferases that synthesize sulfated oligosaccharides on lutropin. Proceedings of the National Academy of Sciences of the USA 90 11127-11131.

Datta AK \& Paulson JC 1995 The sialyltransferase 'sialylmotif' participates in binding the donor substrate CMP-NeuAc. Fournal of Biological Chemistry 270 1497-1500.

Ebling FJP, Wood RI, Vannerson LA, Suttie JM, Buchlotz DC, Karsch FJ, Schall RE \& Foster DL 1990 Metabolic interfaces between growth and reproduction. III. Central mechanisms controlling $\mathrm{LH}$ secretion in the nutritionally growth-limited female lamb. Endocrinology 126 2719-2727.

Esch FS, Mason AJ, Cooksey K, Mercado M \& Shimasaki S 1986 Cloning and DNA sequence analysis of the cDNA for the precursor of the beta chain of bovine follicle-stimulating hormone. Proceedings of the National Academy of Sciences of the USA 83 6618-6621.

Fiddes JC \& Goodman HM 1979 Isolation, cloning and sequence analysis of the cDNA for the alpha-subunit of human chorionic gonadotropin. Nature 281 351-356.

Galle PC, Ulloa-Aguirre A \& Chappel SC 1983 Effects of oestradiol, phenobarbitone and luteinizing hormone releasing hormone upon the isoelectric profile of pituitary folliclestimulating hormone in ovariectomized hamsters. Fournal of Endocrinology 99 31-39.

Galway AB, Hsueh AJW, Keene JL, Yamoto M, Fauser BCJM \& Boime I 1990 In vitro and in vivo bioactivity of recombinant human follicle-stimulating hormone and partially deglycosylated variants secreted by transfected eukaryotic cell lines. Endocrinology 127 93-100.

Gharib SD, Roy A, Wierman ME \& Chin WW 1989 Isolation and characterization of the gene encoding the beta-subunit of rat follicle-stimulating hormone. DNA 8 339-349.

Gharib SD, Wierman ME, Shupnik MA \& Chin WW 1990 Molecular biology of pituitary gonadotropins. Endocrine Reviews 11 177-199.

Glenn TC \& Glenn SJ 1994 Rapid elution of DNA from agarose gels using polyester plug spin inserts (PEPSIs). Trends in Genetics 10344.

Green ED \& Baenziger JU 1988 Asparagine-linked oligosaccharides on lutropin, follitropin, and thyrotropin. II. Distribution of sulfated and sialylated oligosaccharides on bovine, ovine, and human pituitary glycoprotein hormones. Fournal of Biological Chemistry 263 36-44.

Gyves PW, Gesundheit N, Thotakura NR, Stannard BS, DeCherney GS \& Weintraub BD 1990 Change in the sialylation and sulfation of secreted thyrotropin in congenital hypothyroidism. Proceedings of the National Academy of Sciences of the USA 87 3792-3796.

Hassing JM, Kletter GB, I'Anson H, Woods RI, Beitins I, Foster DL \& Padmanabhan V 1993 Pulsatile administration of gonadotropin-releasing hormone does not alter the folliclestimulating hormone (FSH) isoform distribution pattern of pituitary or circulating FSH in nutritionally growth-restricted ovariectomized lambs. Endocrinology 132 1527-1536.

Helton TE \& Magner JA 1994a Sialyltransferase messenger ribonucleic acid increases in thyrotrophs of hypothyroid mice: an in situ hybridization study. Endocrinology 134 2347-2353.

Helton TE \& Magner JA $1994 b$ ß1,4-Galactosyltransferase and a-mannosidase-II messenger ribonucleic acid levels increase with different kinetics in thyrotrophs of hypothyroid mice. Endocrinology 135 1980-1985. 
Kitagawa H \& Paulson JC 1994 Differential expression of five sialyltransferase genes in human tissues. Fournal of Biological Chemistry 27 17872-17878.

Kleen R \& Berger EG 1993 The molecular and cell biology of glycosyltransferases. Biochimica et Biophysica Acta 1154 $283-325$.

Lee JS, Manning JM, Foster DL \& Padmanabhan V 1998 Estrogen increases the secretion of less-acidic FSH isoforms in ovariectomized prepubertal and peripubertal lambs. Program of the 80th Annual Meeting of the Endocrine Society (USA ), New Orleans, LO, 1998, p 348 Abstract P2-474.

Liu TC, Pu HF \& Jackson GL 1992 Divergent roles of protein kinase $\mathrm{C}$ in luteinizing hormone biosynthesis versus release in rat anterior pituitary cells. Endocrinology 131 2711-2716.

Liu TC, Pu HF \& Jackson GL 1994 Differential actions of phospholipase $\mathrm{C}$ on gonadotropin-releasing hormonestimulated release and glycosylation of luteinizing hormone in rat anterior pituitary cells. Neuroendocrinology 60 62-68.

Miller C, Ulloa-Aguirre A, Hyland L \& Chappel SC 1983 Pituitary follicle-stimulating hormone heterogeneity: assessment of biologic activities of each follicle-stimulating hormone form. Fertility and Sterility 40 242-247.

Miura Y, Perkel VS, Papenberg KA, Johnson MJ \& Magner JA 1989 Concanavalin-A, lentil and ricin affinity binding characteristics of human thyrotropin: differences in the sialylation of thyrotropin in sera of euthyroid, primary and central hypothyroid patients. Fournal of Clinical Endocrinology and Metabolism 69 985-995.

Ortolano GA, Haisenleder DJ, Dalkin AC, Iliff-Sizemore SA, Landefeld TD, Maurer RA \& Marshall JC 1988 Folliclestimulating hormone beta subunit messenger ribonucleic acid concentrations during the rat estrous cycle. Endocrinology $1232946-2948$.

Padmanabhan V, Lang LL, Sonstein J, Kelch RP \& Beitins IZ 1988 Modulation of serum follicle-stimulating hormone bioactivity and isoform distribution by estrogenic steroids in normal women and in gonadal dysgenesis. Fournal of Clinical Endocrinology and Metabolism 67 465-473.

Persani L, Borgato S, Romoli R, Asteria C, Pizzocaro A \& Beck-Peccoz P 1998 Changes in the degree of sialylation of carbohydrate chains modify the biological properties of circulating thyrotropin isoforms in various physiological and pathological states. Fournal of Clinical Endocrinology and Metabolism 83 2486-2492.

Pierce JG \& Parsons TF 1981 Glycoprotein hormones: structure and function. Annual Review of Biochemistry $\mathbf{5 0}$ 465-495.

Rafferty B, Mower JA, Ward HL \& Rose M 1995 Differences in carbohydrate composition of FSH preparations detected with lectin-ELISA systems. Fournal of Endocrinology 145 $527-533$.

Reichert LE 1971 Electrophoretic properties of pituitary gonadotropins as studied by electrofocusing. Endocrinology 88 1029-1035.

Sanger F, Nicklen S \& Coulson A 1977 DNA sequencing with chain terminating inhibitors. Proceedings of the National Academy of Sciences of the USA 74 5463-5467.

Schaaf L, Leiprecht A, Saji M, Hübner U, Usadel KH \& Kohn LD 1997 Glycosylation variants of human TSH selectively activate signal transduction pathways. Molecular and Cellular Endocrinology 132 185-194.

Simoni M, Jockenhövel F \& Nieschlag E 1994 Polymorphism of human pituitary FSH: analysis of immunoreactivity and in vitro bioactivity of different molecular species. Fournal of Endocrinology 141 359-367.

Smith MS, Freeman ME \& Neill JD 1975 The control of progesterone secretion during the estrous cycle and early pseudopregnancy in the rat: prolactin, gonadotropin and steroid levels associated with rescue of the corpus luteum of pseudopregnancy. Endocrinology 96 219-226.

Stanton PG, Burgon PG, Hearn MTW \& Robertson DM 1996 Structural and functional characterisation of hFSH and hLH isoforms. Molecular and Cellular Endocrinology 125 133-141.

Stockell Hartree HA \& Renwich GCA 1992 Molecular structures of glycoprotein hormones and functions of their carbohydrate components. Biochemical Fournal 287 665-679.

Ulloa-Aguirre A \& Timossi C 1998 Structure-function relationship of follicle-stimulating hormone and its receptor. Human Reproduction Update 4 260-283.

Ulloa-Aguirre A, Miller C, Hyland L \& Chappel S 1984 Production of all follicle-stimulating hormone isohormones from a purified preparation by neuraminidase digestion. Biology of Reproduction 30 382-387.

Ulloa-Aguirre A, Mejía JJ, Domínguez R, Guevara-Aguirre J, Díaz-Sánchez V \& Larrea F 1986 Microheterogeneity of anterior pituitary FSH in the male rat: isoelectric focusing pattern throughout sexual maturation. Fournal of Endocrinology 110 539-549.

Ulloa-Aguirre A, Espinoza R, Damián-Matsumura P, Larrea F, Flores A, Morales L \& Domínguez R 1988 Studies on the microheterogeneity of anterior pituitary follicle-stimulating hormone in the female rat. Isoelectric focusing pattern throughout the estrous cycle. Biology of Reproduction 38 $70-78$.

Ulloa-Aguirre A, Cravioto A, Damián-Matsumura P, Jiménez M, Zambrano E \& Díaz-Sánchez V $1992 a$ Biological characterization of the naturally occurring analogues of intrapituitary human follicle-stimulating hormone. Human Reproduction 7 23-30.

Ulloa-Aguirre A, Schwall R, Cravioto A, Zambrano E \& Damián-Matsumura P $1992 b$ Effects of gonadotrophinreleasing hormone, recombinant human activin-A and sex steroid hormones upon the follicle-stimulating isohormones secreted by rat anterior pituitary cells in culture. Fournal of Endocrinology 134 97-106.

Ulloa-Aguirre A, Rees Midgley Jr A, Beitins IZ \& Padmanabhan V 1995 Follicle-stimulating isohormones: characterization and physiological relevance. Endocrine Reviews 16 765-787.

Wakeling AE, Dukes M \& Bowler J 1991 A potent specific pure antiestrogen with clinical potential. Cancer Research $\mathbf{5 1}$ 3867-3873.

Watkins PC, Eddy R, Beck AK, Vellucci V, Leverone B, Tanzi RE, Gusella JF \& Shows TB 1987 DNA sequence and regional assignment of the human follicle-stimulating hormone beta-subunit gene to the short arm of human chromosome 11. DNA 6 205-211.

Weinstein J, de Souza-e-Silva U \& Paulson JC 1982 Purification of a Gal $\beta 1 \rightarrow$ GlcNAc $\alpha 2 \rightarrow 6$ sialyltransferase and a Gal $\beta 1 \rightarrow(4)$ GlcNAc $\alpha 2 \rightarrow 3$ sialyltransferase to homogeneity from rat liver. Fournal of Biological Chemistry 257 13835-13844.

Wen DX, Livingston BD, Medzihradszky KF, Kelm S, Burlingame AL \& Paulson JC 1992 Primary structure of Gal $\beta 1,3(4)$ GlcNAc $\alpha 2,3$-sialyltransferase determined by mass spectrometry sequence analysis and molecular cloning. Fournal of Biological Chemistry 267 21011-21019.

Wide L 1982 Male and female forms of human folliclestimulating hormone in serum. Fournal of Clinical Endocrinology and Metabolism 55 682-688.

Wide L 1985 Median charge and charge heterogeneity of human pituitary FSH, LH and TSH. II. Relationship to sex and age. Acta Endocrinologica 109 190-197.

Wide L 1989 Follicle-stimulating hormones in anterior pituitary glands from children and adults differ in relation to sex and age. Fournal of Endocrinology 123 519-529. 
Wide L \& Bakos O 1993 More basic forms of both human follicle-stimulating hormone and luteinizing hormone in serum at midcycle compared with the follicular and luteal phase. Fournal of Clinical Endocrinology and Metabolism 76 885-889.

Wide L \& Naessén T 1994 17ß-Estradiol counteracts the formation of the more acidic isoforms of follicle-stimulating hormone and luteinizing hormone after menopause. Clinical Endocrinology 40 783-789.

Wilson CA, Leigh AJ \& Chapman AJ 1990 Gonadotrophin glycosylation and function. Fournal of Endocrinology 125 3-14.
Zambrano E, Olivares A, Mendez JP, Guerrero L, Díaz-Cueto L, Veldhuis JD \& Ulloa-Aguirre A 1995 Dynamics of basal and gonadotropin-releasing hormone-releasable serum follicle-stimulating hormone charge isoform distribution throughout the human menstrual cycle. Fournal of Clinical Endocrinology and Metabolism 80 1647-1656.

Zambrano E, Barrios-de-Tomasi J, Cárdenas M \& Ulloa-Aguirre A 1996 Studies on the in vitro biological potency of the naturally occurring isoforms of intrapituitary follicle-stimulating hormone. Molecular Human Reproduction 2 563-571.

REVISED MANUSCRIPT RECEIVED 21 April 1999 